\title{
SEASONAL DRIFT-BENTHOS TRENDS ON A MOSS-COVERED TUFA BARRIER WITHIN A KARST BARRAGE HYDROSYSTEM (PLITVICE LAKES, CROATIA)
}

\author{
Mirela Sertić Perić*, Silvija Jakopović \& Biserka Primc \\ University of Zagreb, Faculty of Science, Division of Biology, Department of Zoology, \\ Rooseveltov trg 6, HR-10000 Zagreb, Croatia
}

Sertić Perić, M., Jakopović, S. \& Primc, B.: Seasonal drift-benthos trends on a moss-covered tufa barrier within a karst barrage hydrosystem (Plitvice Lakes, Croatia). Nat. Croat., Vol. 24, No. 2., 223-246, Zagreb, 2015.

Macroinvrtebrate drift and streambed material transport are very important for the redistribution of energy sources and habitat-building elements within lotic ecosystems. The objective of the present study was to examine seasonal drift-benthos trends of macroinvertebrates and organic/inorganic matter particles between barrier and pool habitats at a small spatial scale within a karst barrage hydrosystem (Plitvice Lakes). Benthos and drift were sampled seasonally between November 2006 and July 2007 at four sampling sampling sites representing barrier (B; fast-flow velocity) and pool (P; slow-flow velocity) habitats. During the entire study period, amounts of drifting macroinvertebrates, and organic and inorganic particles were significantly higher at barriers than in pools. In benthos, such barrier trend was found for moss only. Considering seasonal differences, benthos showed no significant tren$\mathrm{ds}$, whereas in drift we found significantly higher loads of all measured items in autumn and winter than in other two seasons, but such trend was observed at barriers only. The quantities of organisms in benthos and drift greatly followed the respective trends of particulate organic and inorganic matter, especially moss. At both habitat types macroinvertebrate drift mostly presented a smaller proportion of total benthos faunal composition, although there were some taxa that occurred in drift or benthos only. In total (including benthos and drift samples), we found 63 taxa during the study - 5 of them were found only within pools, 38 only at barriers and 20 of them were found at both habitat types. The most dominant in both benthos and drift, were Oligochaeta, cladoceran Alona spp., Copepoda, and larval stages of coleopteran Riolus spp. and dipteran Simulium spp. Most of them belong to mobile, epiphytic and/or interstitial detritivores that most likely originated from the submerged aquatic vegetation (i.e., moss), floating leaf litter and/or sediments along our study reach, whereas cladoceran and copepod taxa likely originated from the upstream lake. The observed seasonality in the faunal drift-benthos composition (e.g., Cladocera increase in summer and autumn, Ephemeroptera decrease/absence in winter and spring), was likely a consequence of the seasonal food sourcing for individual taxa, and their particular life history traits. Our findings suggest that within the tufa-precipitating Plitvice Lakes hydrosystem: a) drift has a very important role in maintaining benthos structure and stability within the barrier and pool habitats; b) tufa barriers are highly dynamic habitats, characterized by pronounced season-specific dislodgement of the benthic organisms and particulate matter, and effective moss-mediated macroinvertebrate dispersal; $\mathrm{c}$ ) the abundance of macroinvertebrates and the amounts of organic/inorganic particles in drift are influenced not only by flow velocity and the seasonal lake discharges/biocommunity dynamics, but also by the initial distribution of particles/organisms within benthos as well as by the life history traits of the individual benthic organisms.

Keywords: tufa barriers, pools, moss, drift, benthic macrofauna, Plitvice Lakes

*Corresponding author, E-mail: mirela.sertic.peric@biol.pmf.hr 
Sertić Perić, M., Jakopović, S. \& Primc, B.: Sezonski trendovi drifta i bentosa na mahovinom prekrivenim sedrenim barijerama unutar krškog baražnog hidrosustava (Plitvička jezera, Hrvatska). Nat. Croat., Vol. 24, No. 2., 223-246, Zagreb, 2015.

Nizvodno otplavljivanje (drift) bentoskih makrobeskralježnjaka i supstrata je važan mehanizam (pre)raspodjele energetskih izvora i građevnih elemenata staništa u lotičkim ekosustavima. Cilj ovog istraživanja bio je istražiti sezonske trendove drifta i bentosa na barijerama i u ujezerenjima na maloj prostornoj skali unutar krškog baražnog hidrosustava Plitvičkih jezera. Uzorkovanje makrobeskralježnjaka i usitnjene organske/anorganske tvari u driftu i bentosu provedeno je sezonski između studenog 2006. i srpnja 2007. na četiri postaje, koje su predstavljale dva tipa staništa: barijere (B; staništa s brzom strujom vode) i ujezerenja (P; staništa sa sporom strujom vode). Tijekom cijelog razdoblja istraživanja, ukupna brojnost makrozoobentosa i količina organskih/anorganskih tvari u driftu bile su značajno više na barijerama nego u ujezerenjima. U bentosu je takva razlika među tipovima staništa opažena samo s obzirom na količinu mahovina. $S$ obzirom na sezonske razlike, $u$ bentosu nisu opažene značajnije trendovi, dok su u driftu u jesen i zimu nađene značajno veće količine organske i anorganske tvari i organizama nego u preostale dvije sezone, ali takav je trend opažen samo na barijerama. Brojnost organizama u bentosu i driftu uvelike je slijedila trendove količina usitnjene organske i anorganske tvari, osobito mahovina. U oba tipa staništa, taksonomski sastav drifta uglavnom je odražavao sastav bentosa. Međutim, u driftu su pronađeni organizmi koji nisu bili zastupljeni u bentosu i obrnuto. Ukupno tijekom istraživanja nađene su 63 svojte u uzorcima bentosa i drifta - od toga je 5 svojti nađeno samo u ujezerenjima, 38 samo na barijerama, a 20 svojti na oba tipa staništa. Najdominantniji i u bentosu i u driftu bili su Oligochaeta, rašljoticalac Alona spp., Copepoda te ličinke kornjaša Riolus spp. i dvokrilaca Simulium spp. Većina njih pripada mobilnim, epifitskim i/ili intersticijskim detritivorima, za koje pretpostavljamo da na našim postajama istraživanja dolaze na podvodnoj vegetaciji (tj. mahovini), plutajućim listovima i/ili u samom supstratu, dok za predstavnike Cladocera i Copepoda smatramo da potječu iz uzvodnog jezera. Opažene sezonske trendove $\mathrm{u}$ taksonomskom sastavu drifta i bentosa (npr. povećanje brojnosti Cladocera u ljeto i jesen; smanjenje brojnosti/odsutnost Ephemeroptera u proljeće i zimu) objašnjavamo kao posljedicu sezonskih razlika u izvorima hrane i životnim ciklusima pojedinih svojti. Naši rezultati ukazuju da u sedrotvornom sustavu Plitvičkih jezera: a) drift ima vrlo važnu ulogu u održavanju strukture i stabilnosti bentosa na različitim tipovima staništa (na barijerama i u ujezerenjima); b) sedrene barijere su vrlo dinamična staništa, u kojima je snažno izraženo sezonsko otplavljivanje bentoskih organizama i usitnjene organske/anorganske tvari, a osobito mahovina kojima se može pripisati vrlo važna uloga prijenosnika pri nizvodnom transportu tvari i organizama; c) na brojnost makrozoobentosa i količinu organskih/anorganskih tvari u driftu, izuzev brzine strujanja vode i sezonskih razlika u jezerskom utjecaju (tj. jezerskom protoku i životnim zajednicama), u velikoj mjeri utječu i inicijalni sastav i raspodjela čestica/organizama u bentosu te ekološko-etološke osobitosti pojedinih skupina organizama.

Ključne riječi: sedrene barijere, ujezerenja, mahovina, drift, makrofauna bentosa, Plitvička jezera

\section{INTRODUCTION}

Tufa barriers are the most prominent features of the porous biogenic calcareous deposits within the Croatian National park Plitvice Lakes. They have globally been recognized as "hot spots" of biological diversity and activity (e.g., CARTHEw et al., 2002; Pentecost, 2005; Pedley \& Rogerson, 2010; Sertić Perić et al., 2011). As they are often interconnected with barrage lakes, waterfalls, water cascades, channels and pools, and covered with dense periphyton and moss mats, they provide specific and diverse hydromorphological habitat conditions. Although tufa barriers represent very dynamic habitats, the corresponding moss coverage is considered to increase the barrier habitat stability as well as refugia availability for many organisms (SuREN, 1991). The filamentous habitus of aquatic mosses reduce flow currents within their matrices; stabilize substrate; restrain erosion; provide a large surface for colonization of many periphytic organisms; and also collect abundant coarse, fine and ultrafine organic particles that 
serve as food to many moss-dwelling organisms, mostly benthic macroinvertebrates and meiofauna (e.g., Suren, 1992; MilišA et al., 2006a; DrAŽınA et al., 2013).

The previous studies within the tufa-precipitating Plitvice Lakes hydrosystem have suggested that the spatio-temporal dynamics of biota within the moss-covered tufa barriers is greatly affected by seasonal changes in hydrochemistry, water temperature and tufa precipitation rates (MatoničKin KePČija et al., 2006; MilišA et al., 2006a,b; Sertić Perić et al., 2011). As well, it was shown that the increased removal and downstream transport of moss during colder seasons (autumn, winter) within Plitvice Lakes could serve as an important vector mechanism in dispersing macroinvertebrates, and organic and inorganic particulate matter (SERTić Perić et al., 2011). The downstream transport and dispersal of benthic macroinvertebrates (i.e., macroinvertebrate drift), in-stream sediment and organic particulate matter is considered crucial for the efficient re-distribution of energy sources and habitat-building elements within lotic ecosystems (e.g., Allan, 1995; Hoover et al., 2010 and references therein).

Macroinvertebrate drift might be purely behavioral (i.e., "active"; intentional; biotically-affected; influenced by invertebrate life history traits/events, avoidance of predators and/or competitive interactions); but it is also vastly abiotically-affected (i.e., "passive"; accidental/unintentional dislodgement; influenced by environmental changes/ habitat characteristics) and thus greatly depends on flow conditions; shape, type and roughness of the channel; and overall streambed heterogeneity (LAMBERTI \& Gregory, 2006; Sмоск, 2007 and references therein). Accordingly, content of macroinvertebrates, and organic/substrate particles in benthos and drift may greatly vary between in-stream erosional (e.g., riffles, barriers) and depositional areas (e.g., pools) (WALLACE et al., 2007; HAuer et al., 2012).

Previous ecological studies of the Plitvice Lakes hydrosystem have extensively explored the effect of flow velocity on periphyton, seston, benthic meio- and macrofauna and their drift patterns, organic matter distribution (i.e., food supply) and leaf litter breakdown (e.g., Primc-Habdija et al., 2001; Habdija et al., 2004; MatoničKin Kepčija et al., 2006; Miliša et al., 2006a, b; Špoljar et al., 2007a, b; Belančić et al., 2009; Sertić Perić et al., 2011, 2014; DražınA et al., 2013). However, none of these ecosystem properties were investigated simultaneously (i.e., they were all segments of separate studies), so we have never captured a broader view of the effects of adverse flow conditions within this unique hydrosystem. To our knowledge, this is a first year-round study simultaneously exploring benthos and drift (including macroinvertebrates, organic and inorganic matter) within barriers and pools of a tufa-depositing, moss-rich karst barrage Plitvice Lakes hydrosystem.

The objective of the study was to examine seasonal differences in the composition of benthic and drifting macroinvertebrates, and associated organic and inorganic matter particles among barriers and pools at a small spatial scale within a study reach at the Plitvice Lakes. Considering the retentive properties of moss (Sertić Perić et al. 2011; 2014), we expected that the spatio-temporal patterns of drift and benthos within our study system would follow the spatial (i.e., barrier vs pool) and temporal (i.e., seasonal) trends of the in-stream moss contents. We further anticipated that the macroinvertebrate drift-benthos shifts would reflect life history traits of individual taxa, which are likely closely linked to the inter-habitat (i.e., barrier vs pool) and seasonal environmental conditions, and the organism dispersal/mobility strategies. 


\section{MATERIAL AND METHODS}

\section{Study system and sampling sites}

The present study was conducted in the Croatian National Park (NP) Plitvice Lakes $\left(44^{\circ} 53^{\prime} \mathrm{N}, 15^{\circ} 37^{\prime} \mathrm{E}\right)$, located in the inland mountain region of Croatia (Fig. 1a). The basic phenomenon of the NP is a formation of a porous calcareous precipitate (tufa) that shapes a cascade system of 16 oligotrophic barrage lakes interconnected by tufa barriers, waterfalls and cascades, channels and rapids. The lake cascade descends from an altitude of 636 to $503 \mathrm{~m}$ a.s.l. over a distance of $8.2 \mathrm{~km}$ and is divided into two clusters: (1) the Upper Lakes situated on less permeable dolomite and (2) the Lower Lakes placed in a narrow canyon composed of very permeable limestone.

The formation and physico-chemical and biological properties of the Plitvice Lakes, tufa and accompanying features greatly depend on the interaction between water ambient temperatures, $\mathrm{pH}$, carbonate biochemistry, discharge (i.e., water flow velocity) and resident organisms. More details on the tufa precipitating factors within the Plitvice

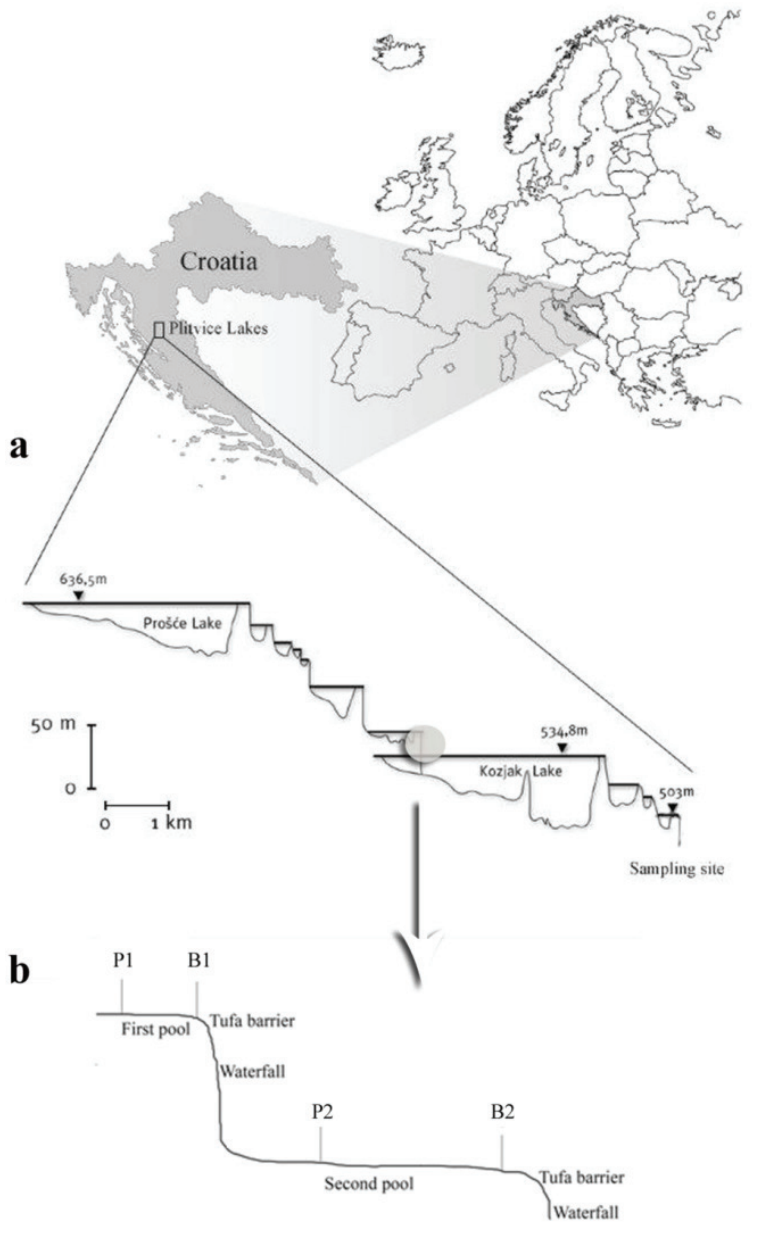

Fig. 1 Map of Croatia with: (a) enlargements of the Plitvice Lakes study system and location of the study reach (shadowed); (b) schematic spatial distribution of the four sampling sites along the study reach (adjusted to Dražina et al. 2014 and Sertić Perić et al. 2011). 


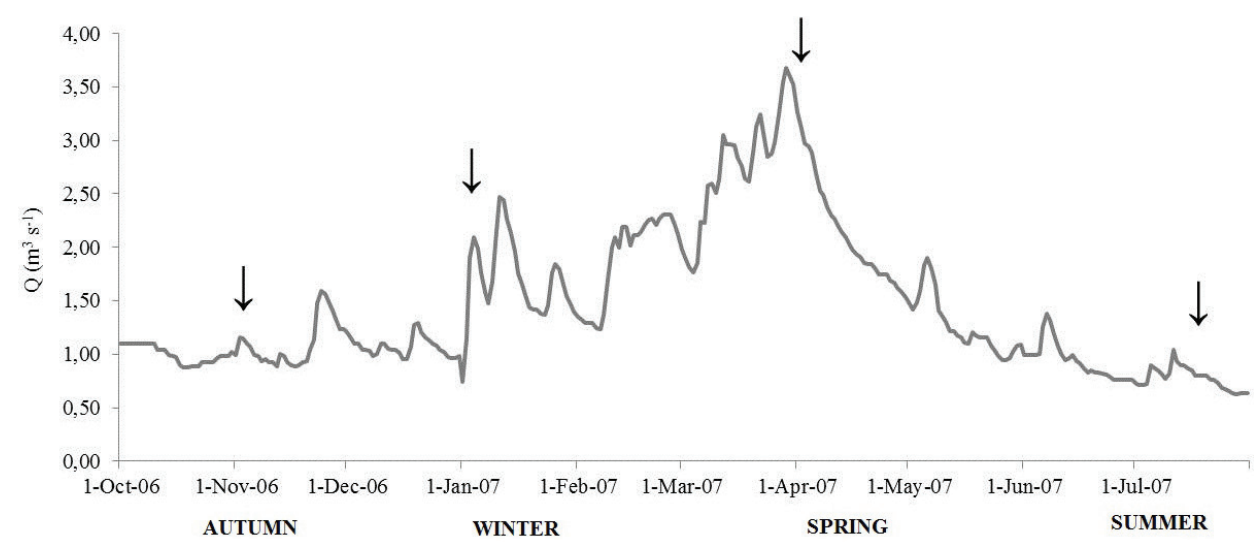

Fig. 2 Daily discharge records during the study period. Sampling dates are indicated by arrows.

Lakes are given in previous studies of the Lakes (e.g., SRdoč et al., 1985; Golubić et al., 2008). A general range of the environmental (i.e., water) parameters relevant for this study are evident from the annual physico-chemical record presented in SERTIĆ PERIĆ et al. $(2011 ; 2014)$. According to daily discharge records obtained from the gauging station Kozjak Most of the State Meteorological and Hydrological Service located at Kozjak Lake (533 m a.s.1.; about $1800 \mathrm{~m}$ downstream of our study area), mean water discharge within the study system during the present study was $1.7 \mathrm{~m}^{3} \mathrm{~s}^{-1}$ (range: $0.7-2.9 \mathrm{~m}^{3} \mathrm{~s}^{-1}$; standard deviation, $\mathrm{SD}=1.0 \mathrm{~m}^{3} \mathrm{~s}^{-1}$; coefficient of variation, $\mathrm{CV}=57 \%$ ) (Fig. 2). The gauging station "Kozjak Most" is used to collect long-term flow data, and it most accurately represents hydrologic variability in the upstream study area as it is closest to it, and there are no major tributaries between the study area and the station.

Our study area was located within the Upper Lakes between the Veliki Burget (553 $\mathrm{m}$ a.s.l.; area: 1 ha; depth: $5 \mathrm{~m}$ ) and Kozjak (535 m a.s.1.; area: 81.5 ha; depth: $47 \mathrm{~m}$ ) lakes. It is about $15 \mathrm{~m}$-long stretch, located at the outlet of the Lake Veliki Burget and consisting of two tufa barriers with waterfall and a shallow pool in-between (Figs. $1 \mathrm{~b}$ and 3 ). The study area included: (i) the slow-flowing part (i.e., pool P1) closest to the upstream lake; (ii) the barrier B1 that creates about $1 \mathrm{~m}$-high waterfall; (iii) the pool P2, which is located between the barrier B1 and (iv) another barrier (B2) that ends with an abrupt waterfall cascade flowing into Kozjak lake.

The four sampling sites (B1, B2, P1, P2) were chosen to represent replicate units of the two habitat types - barriers (B; fast-flowing habitats) and pools (P; slow-flowing habitats), which differed in their water column depth, flow conditions and substratum composition (Tab. 1, Fig. 4). The distance between individual sampling sites was about 3-5 m, enabling the small-scale assessment of benthos and drift.

\section{General sampling design}

Field sampling was designed seasonally and it was conducted on the following dates: November 2, 2006 (autumn); January 4, 2007 (winter); April 3, 2007 (spring) and July 23, 2007 (summer). On each sampling date at each sampling site, the in-stream morpholo- 


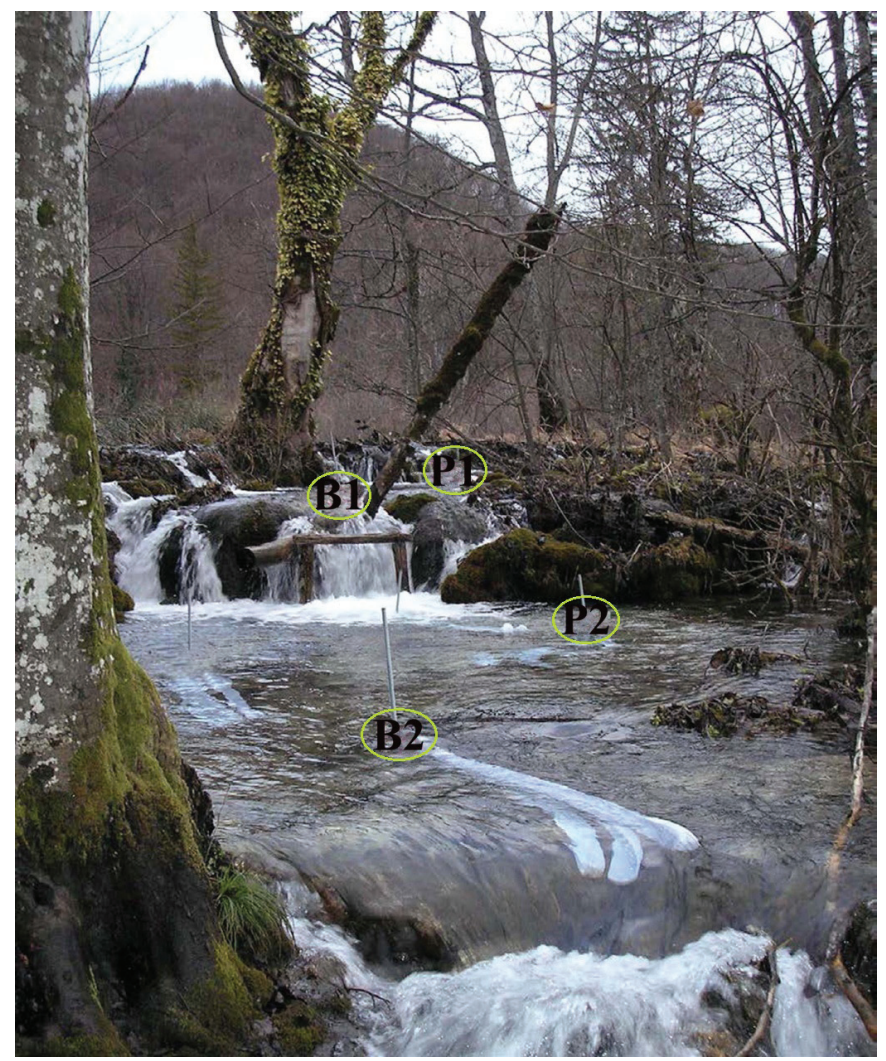

Fig. 3 In situ placement of the four sampling sites along the study reach (photo by: M. Sertić Perić; taken during drift sampling).

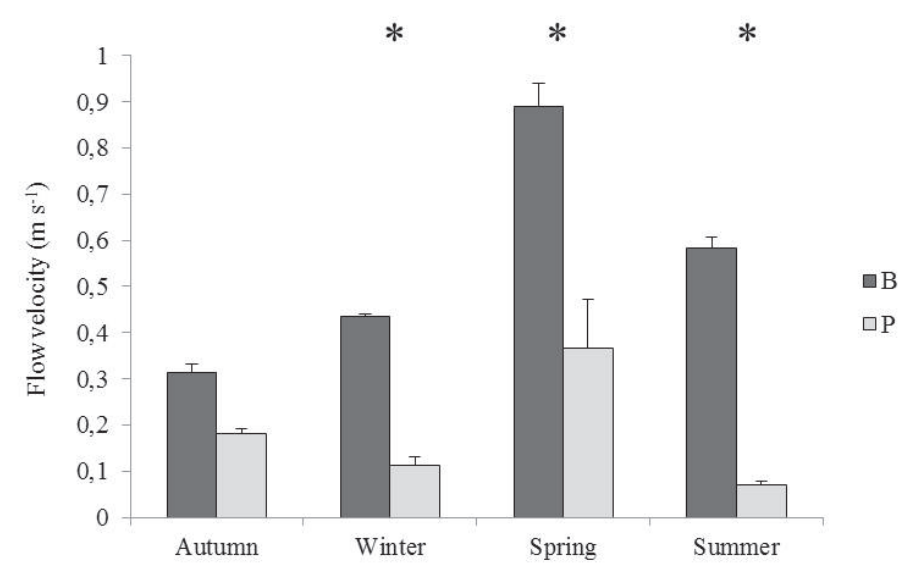

Fig. 4 Seasonal dynamics of flow velocity (mean $+\mathrm{SE}$ ) at barriers $(\mathrm{B})$ and pools $(\mathrm{P})$ within our study reach. Asterisks denote significant flow differences (Mann-Whitney U-test, $\mathrm{p}<$ 0.05) between the two microhabitat types. 
Tab. 1. Hydromorphological features of the investigated sampling sites during the study period.

\begin{tabular}{|l|l|c|c|c|c|}
\hline Microhabitat type & \multicolumn{2}{|c|}{ Barrier } & \multicolumn{2}{c|}{ Pool } \\
\hline Sampling site & \multicolumn{2}{|c|}{ B1 } & B2 & P1 & P2 \\
\hline Substratum type & \multicolumn{2}{|c|}{ Porous tufa blocks + moss } & $\begin{array}{c}\text { Silt-laden tufa }+ \\
\text { moss }\end{array}$ & $\begin{array}{c}\text { Tufa sand + } \\
\text { moss }\end{array}$ \\
\hline Relative moss coverage & \multicolumn{2}{|c|}{ abundant } & frequent & occasional \\
\hline Flow velocity $\left(\mathrm{m} \mathrm{s}^{-1}\right)$ & MEAN \pm SE & $1.06 \pm 0.35$ & $0.43 \pm 0.08$ & $0.15 \pm 0.07$ & $0.06 \pm 0.03$ \\
\hline & CV $(\%)$ & 65 & 39 & 99 & 87 \\
\hline Depth $(\mathrm{m})$ & MIN-MAX & $0.25-0.30$ & $0.50-0.60$ & $0.40-0.45$ & $0.50-0.65$ \\
\hline
\end{tabular}

gical features were determined visually (habitat/substratum type, bottom cover) or by assessment measurements (channel depth) at the individual sampling sites.

At each site-habitat type, benthos was sampled with a core sampler $(\mathrm{r}=2.4 \mathrm{~cm}, \mathrm{~h}=$ $10 \mathrm{~cm}, \mathrm{~V} \approx 181 \mathrm{~cm}^{3}$ ). We then separated the upper $3 \mathrm{~cm}$ (i.e., $\mathrm{V}=54.3 \mathrm{~cm}^{3}$ ) of each core sample to analyze benthic macroinvertebrate composition, and benthic organic and inorganic particulate matter (PM) content. Drifting benthic macroinvertebrates and associated organic and inorganic PM were collected during two-hour sampling events using drift samplers, i.e. cylindrical plastic tubes (50-cm long, inner diameter $7.5 \mathrm{~cm}$; aperture $44.2 \mathrm{~cm}^{2}$ ) fitted with a 1.5-m long net (mesh-size $214 \mu \mathrm{m}$ ). At sites P2 and B2, three drift samples at three cross-sectional depths were taken simultaneously, whereas at sites P1 and B1 only a single drift sample could be taken due to inadequate width and depth of the channel. At each site, the drift samples were taken twice a day (at midday and dusk) to account for the possible effects of diel drift periodicity (e.g., ElLiotT, 1969). The flow velocity (FV) was measured (P600, Dostmann electronic $\mathrm{GmbH}$ ) at the aperture of each sampler after the initial hour of sampling to standardize drift variables per unit volume of water, and to estimate the FV differences between the habitat types. The applied drift sampling design and methodology were designed to be a balance between multiple potential macroinvertebrate drift constraints (i.e., differing flow velocities along the study reach, net clogging, variations in sampled volume) (FAULKNER \& Copp, 2001). All benthos and drift samples were preserved in situ with $4 \%$ formaldehyde solution and transported to the laboratory.

\section{Laboratory procedures}

In the laboratory, macroinvertebrates and moss fragments (MOSS) were separated from each benthos and drift sample. Invertebrates were identified to the lowest possible taxonomic level (genus in most cases; subfamily for Chironomidae; family for Oligochaeta, Copepoda, Collembola, and early insect larval stages; mites were grouped as Hydrachnidia) using a stereomicroscope (Zeiss Stemi 2000-C) and available taxonomic keys (Knoz, 1965; Margaritora, 1983; Amoros, 1984; Schmedtje \& Kohmann, 1988; NiLSSON, 1996, 1997; WARINGer \& Graf, 1997; Di SABATino et al., 2000; TACHÉT et al., 2000; Bauernfeind \& Humpesch, 2001; Sundermann \& Lohse, 2004; Zwick, 2004).

After removing the organisms and MOSS, all benthos and drift sample remains were sieved through nested nets (1-mm and $50-\mu \mathrm{m}$ mesh size) to separate coarse ( $>1 \mathrm{~mm}$; 
$\mathrm{CPOM}$ ) and fine (1 $\mathrm{mm}$ to $50 \mu \mathrm{m}$; FPOM) particulate organic matter (POM) size-fractions. More precisely, the label CPOM refers to coarse particulates apart from MOSS and the label FPOM in drift samples refers to a FPOM fraction between $214 \mu \mathrm{m}$ and $1 \mathrm{~mm}$, as we might have lost the drifting material $<214 \mu \mathrm{m}$ due to the usage of $214-\mu \mathrm{m}$ driftnets. After separation, MOSS and POM size-fractions were dried at $104^{\circ} \mathrm{C}$ until constant weight, ashed at $400^{\circ} \mathrm{C}$ for 4 hours, and reweighed to estimate MOSS, CPOM and FPOM as ash-free dry mass (AFDM), expressed in [ $\left.\mathrm{g} \mathrm{dm}^{-3}\right]$ within each benthos, and [ $100 \mathrm{~m}^{-3}$ ] in each drift sample. The sample contents remained after ashing were estimated as the amount of inorganic matter. Inorganic residuals remained after ashing moss stems were expressed as "moss-attached" tufa (MAT), since it was observed that mosses included much bound tufa; the residuals remained after ashing CPOM and FPOM were summed and expressed together as "non-moss-attached" tufa (non-MAT).

\section{Data analysis}

The recorded benthos and drift parameters, i.e., AFDM of MOSS, CPOM and FPOM; MAT and non-MAT contents; and numbers of macroinvertebrate individuals were expressed per unit volume of substratum and water, respectively. Benthos parameters were expressed per $\mathrm{dm}^{3}$ of substratum and drift per $100 \mathrm{~m}^{3}$ of water (Sмоск, 2007).

The spatio-temporal trends of benthos and drift were tested for significant differences using non-parametric statistics, as the selected parameters were not normally distributed and could not be normalized by common transformations. A Mann-Whitney (M-W) U-test was used for analyzing the respective differences between the two habitat types (i.e., barriers vs. pools) (ZAR, 1984), whereas a Kruskal-Wallis (K-W) test, coupled with multiple comparison post-hoc procedure, was employed for testing the seasonal differences of the selected parameters (STATistica 9.1, STATSoft, INC., 2010).

\section{RESULTS}

\section{Organic and inorganic matter in benthos and drift}

Total benthos and drift amounts of the particulate matter items (MOSS, CPOM, FPOM, MAT and non-MAT) measured along our study area suggest that the two habitat types (i.e., barriers, pools) are quite uniform regarding the benthos parameters, but significantly different regarding the drift trends (Fig. 5). During the entire study period, amounts of drifting macroinvertebrates, and organic and inorganic particles were significantly higher $(\mathrm{M}-\mathrm{W}-\mathrm{U}$ test, $p<0.01)$ at barriers than in pools. In benthos, such barrier trend was found for moss only (M-W-U test, $p<0.05)$ (Fig. 5). MOSS in drift was almost 7-fold higher at barriers than in pools, and this difference within benthos was only 3-fold. MAT showed the same benthos-drift trends as MOSS, whereas CPOM, FPOM and nonMAT trends were reversed. They reached up to 2-fold higher loads in pools than in barrier-benthos, but in drift they reached up to 4-fold higher amounts at barriers in comparison to pools (Fig. 5).

When observing temporal patterns in benthos, not a single season showed significant differences between barriers and pools regarding the benthic particulate matter loads (M-W test; $p>0.05$ across all seasons and particle types; Fig. 6). However, the respective drift data indicated highly significant differences between the two habitat types over individual seasons. In autumn and winter, all organic and inorganic particles in drift 


\section{Benthos}

a)

c)
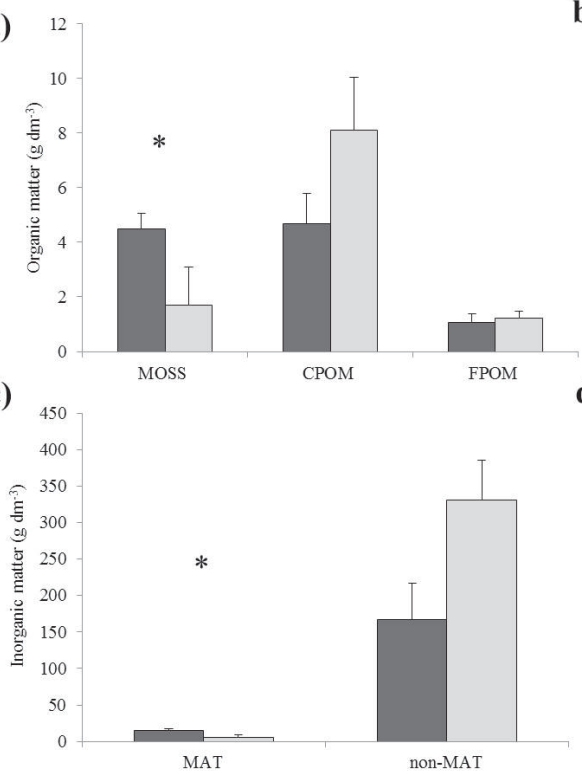

b)

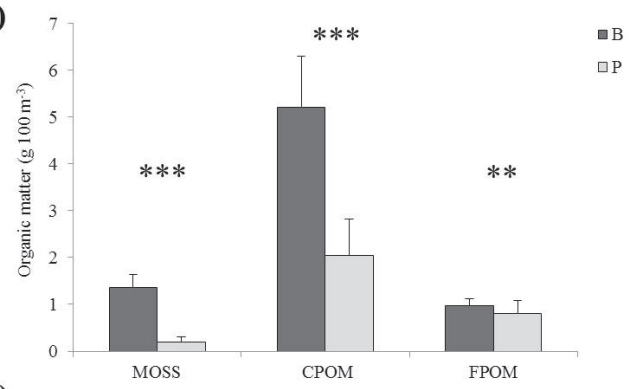

d)

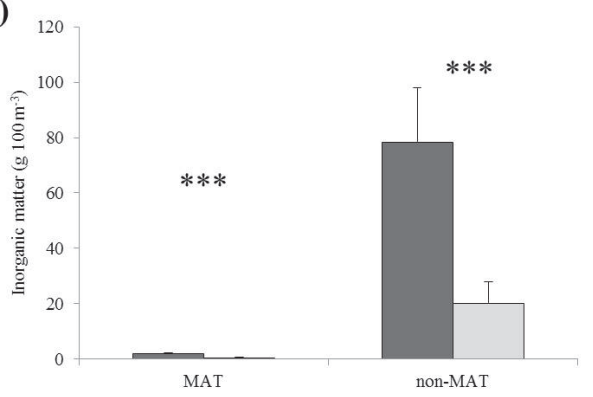

Fig. 5 Mean (+SE) amounts of the organic (a, b) and inorganic (c, d) matter components found in benthos and drift at the two microhabitat types during the study period. Abbreviations are explained in material and methods. Asterisks indicate significant differences (MannWhitney U-test, ${ }^{*} \mathrm{p}<0.05,{ }^{* *} \mathrm{p}<0.01,{ }^{* * *} \mathrm{p}<0.001$ ) between the microhabitat types regarding the amounts of the respective components. Note scaling of axes.

were significantly higher at barriers in comparison to pools (M-W test; $0.001<p<0.05$ ), whereas in spring and summer such trend was observed only for MOSS and MAT (M-W test; $0.01<p<0.05$; Fig. 6).

Benthos of both habitat types showed no seasonal patterns (K-W test, $p>0.05$ ) considering the amounts of the measured organic and inorganic matter (Fig. 6a, c). However, we observed an interesting, although statistically insignificant ( $\mathrm{K}-\mathrm{W}$ test, $p>0.05)$ trend showing that pools accumulated maximal and barriers minimal amounts of MOSS in benthos during winter. During spring the reversed trend was observed - barriers then had maximal and pools minimal amounts of benthic MOSS. The following benthic trends were also apparent, although not proven statistically significant (K-W test, $p>0.05)$ : 1) spring was the season of highest CPOM levels within pool benthos, but at the same time within barrier benthos, it hit the lowest levels; 2 ) at both habitat types, FPOM and MAT reached maximal amounts in benthos during autumn and winter; whereas 3) during winter, within both habitat types, benthic non-MAT reached its minimum (Fig. $6 a, c)$.

Unlike benthos, drift showed some clear seasonal trends, which were proven significant mostly at barriers. At barriers, all drifting particles - organic and inorganic - reached minimal amounts in spring samples (taken after a hydropeaking event), and maximal in autumn (MOSS, CPOM) and winter (FPOM, MAT, non-MAT) samples, which 
Benthos
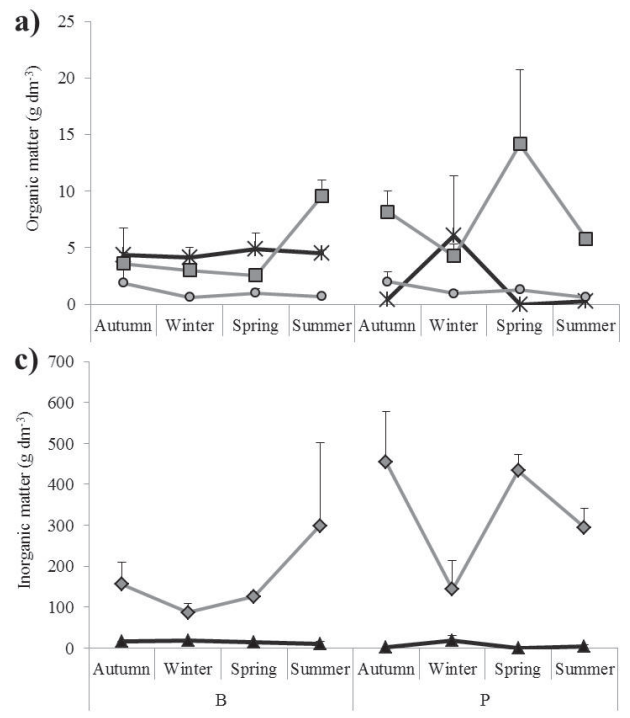

Drift

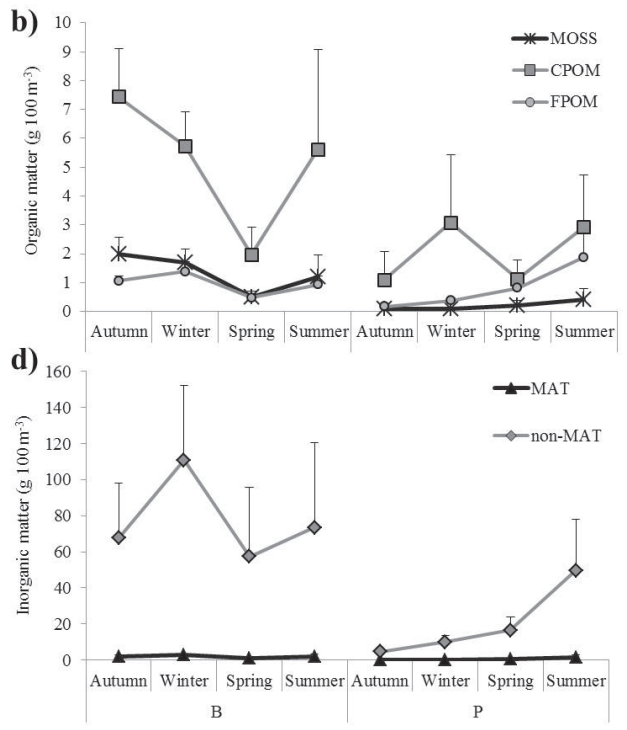

Fig. 6 Seasonal dynamics of the mean (+SE) amounts of the organic (a, b) and inorganic (c, d) matter components found in benthos and drift at the two microhabitat types during the study period. Abbreviations are explained in material and methods. Note scaling of axes.

were taken during hydropeaking events (Figs. 2 and 6b, d). Significant differences between the observed extremes were only evident for MOSS (K-W test; $\mathrm{H}_{(3, \mathrm{~N}=30)}=9.42$, $p<0.05), \operatorname{CPOM}\left(\mathrm{H}_{(3, \mathrm{~N}=30)}=7.87, p<0.05\right)$ and FPOM $\left(\mathrm{H}_{(3, \mathrm{~N}=30)}=9.37, p<0.05\right)$. Within pools, minima of most drifting particles were observed during peaking discharges - in autumn (for CPOM, FPOM, MAT, non-MAT) and winter (for MOSS). The relevant maxima were reached after a hydropeaking event in summer (for MOSS, FPOM, MAT and non-MAT) and during winter discharge peak (for CPOM). The only significant seasonal trend in pools was the one observed for FPOM $\left(\mathrm{K}-\mathrm{W}\right.$ test; $\left.\mathrm{H}_{(3, \mathrm{~N}=32)}=13.96, p<0.01\right)$.
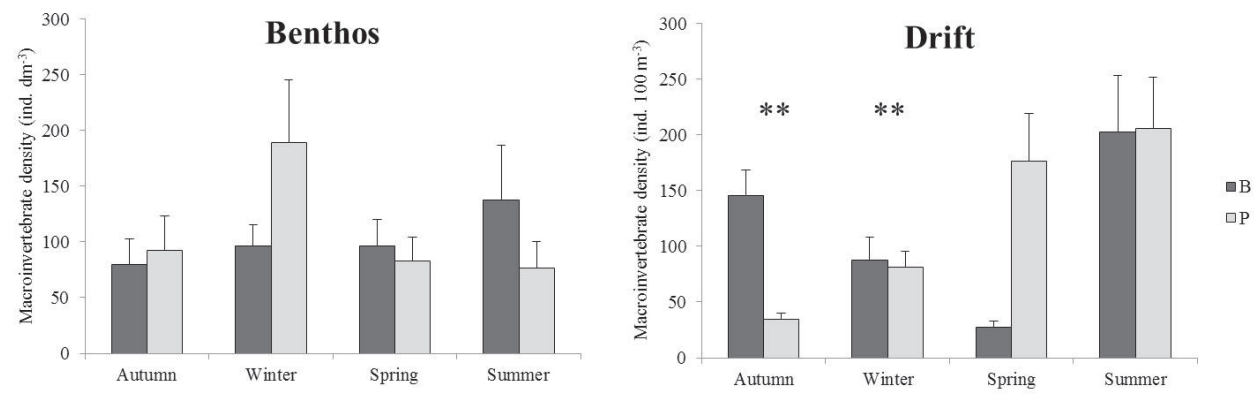

Fig. 7 Mean (+SE) benthic and drift densities of macroinvertebrates at the two microhabitat types during the four seasons. Asterisks indicate seasons in which significant differences between microhabitat types regarding the macroinvertebrate trends were observed (MannWhitney U-test, $\left.{ }^{* *} \mathrm{p}<0.01\right)$. 
Autumn
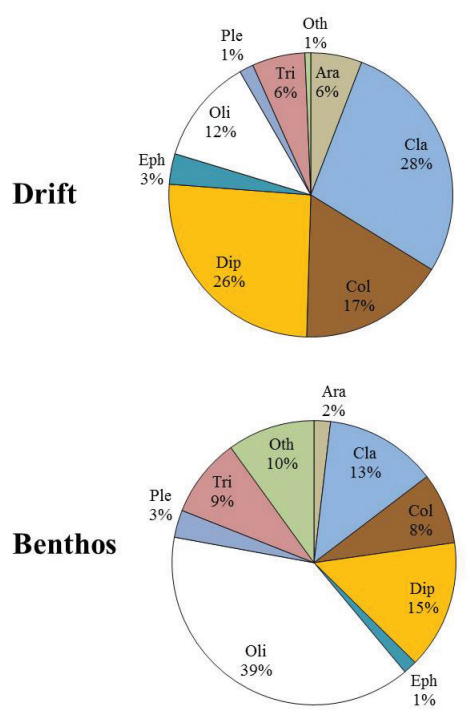

Spring
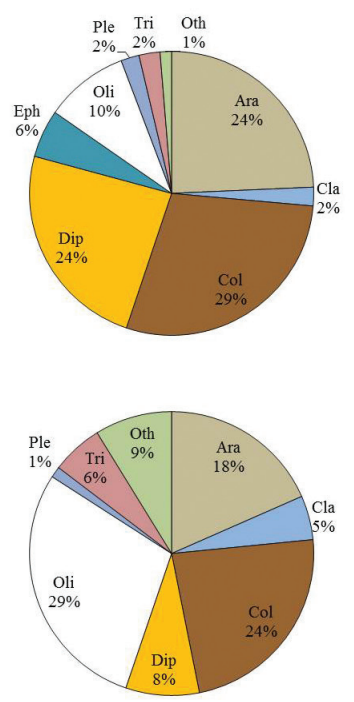

Winter
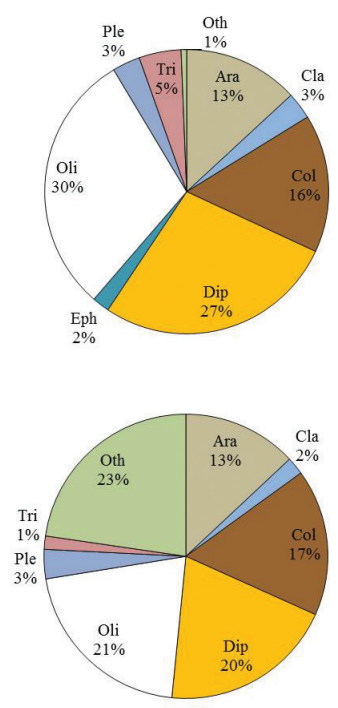

Summer
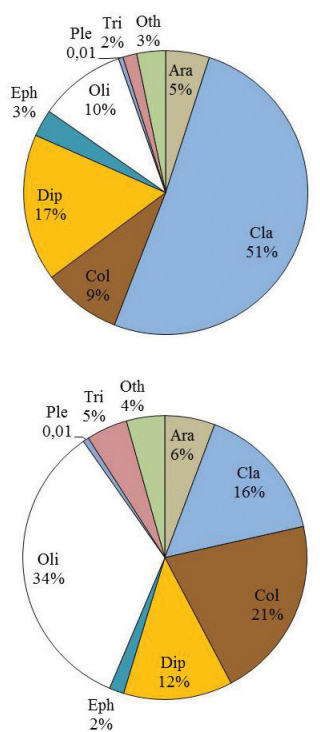

Fig. 8 Contribution of individual taxa to overall benthos and drift densities during the four seasons. For the more detailed overview of the taxa composition and total number of their individuals captured in benthos and drift at individual microhabitat types during the study period, please refer to Tab. 2. Abbreviations: Ara - Arachnida, Cla - Cladocera, Col - Coleoptera, Dip - Diptera, Eph - Ephemeroptera, Oli - Oligochaeta, Ple - Plecoptera, Tri - Trichoptera, Oth - other taxa including Gastropoda, Amphipoda, Copepoda, Ostracoda, Collembola, Odonata and, Ephemeroptera (the latter is included in Oth only in Winter-Benthos, whereas in Spring-Benthos Ephemeroptera were not found). 


\section{Benthic and drifting macroinvertebrates at barriers and pools}

Macroinvertebrate patterns followed the similar barrier and pool trends as particulate matter. Total, as well as individual seasonal records of macroinvertebrate benthic densities yielded no significant differences between barriers and pools (M-W test; $\mathrm{p}$ > 0.05) (Fig. 7). To the contrary, overall drift records showed that, in comparison to pools, barriers had significantly more macroinvertebrate individuals in drift during the entire study period (M-W test; $p<0.001)$. On the individual season level, the trend of significantly higher barrier drift was observed during autumn and winter $(M-W$ test; $p<0.01)$, whereas in spring and summer these drift differences between the two habitat types were lost (M-W test; $\mathrm{p}>0.05)$ (Fig. 7).

At both habitat types macroinvertebrate drift mostly presented a smaller proportion of total benthos faunal composition (Tab. 2, Fig. 8). However, there were some taxa that appeared in drift or benthos only. For example, all the members of Gastropoda were found exclusively in benthos, whereas many (e.g., smaller sized) Trichoptera were found only in drift (Tab. 2). Ephemeroptera were continuously found in some amounts in drift, whereas in benthos they were very rare (i.e., in winter they contributed $<1 \%$ to the winter total abundance) or completely absent (i.e., in spring) (Tab. 2, Fig. 8). Furthermore, Oligochaeta and Trichoptera continuously contributed more to benthos than to drift, but in winter it was the opposite. Cladocera and Diptera mostly had higher proportions within drift (especially in warmer seasons), whereas Plecoptera, Arachnida and Coleoptera had nearly equal proportions within benthos and drift. However, the latter two showed an increasing tendency to drift in autumn and spring, and Coleoptera exhibited lower drift proportion in summer (Fig. 8).

In total we found 63 taxa during the study (in benthos and/or drift) - 5 of them were found only within pools, 38 only at barriers and 20 of them were found at both habitat types (Tab. 2). Overall, the most numerous taxa in benthos at both habitat types were the representatives of Oligochaeta and in drift it was cladoceran Alona spp. Also numerous, with $>1000$ individuals per unit volume of benthos and/or drift, were the representatives of Copepoda (with Cyclopoida found in drift and Harpacticoida in benthos only), and coleopteran (i.e., Riolus spp.) and dipteran (i.e., Simulium spp.) larvae. The latter were numerous only in drift, while their respective benthic densities were $<1000$ ind. $\mathrm{dm}^{-3}$. The increased numbers of Hydrachnidia, and larval Paraleptophlebia sp., $\mathrm{Hy}$ dropsyche sp., Elodes sp., Hemerodromia spp. and representatives of Orthocladiinae were found at barriers only (Tab. 2). Thereby, Hydrachnidia were found numerous in both benthos and drift, and other taxa in drift only.

\section{DISCUSSION}

\section{Spatial (barrier vs. pool) drift-benthos trends}

In general, our results indicate that the moss-rich tufa barriers are highly dynamic habitats, recognized primarily for abrupt changes in gradient (i.e., waterfalls), increased flow velocities (Fig. 4) and considerable hydraulic disturbances, which then likely affect the respective drift-benthos relationships.

Many recent studies point to moss as a key retentive feature in aquatic ecosystems, and evidence the potential of moss to greatly enhance the availability of organic material to benthic consumers (e.g., Suren \& Winterbourn, 1992; Linhart et al., 2002; MuotKA \& LaAsonsen, 2002; Miliša et al., 2006a). As the barriers' benthos along our study 
Tab. 2. Total number of individuals captured in benthos and drift at barriers and pools along the study area during the study period. Insect taxa identified are primarily larval (unless indicated otherwise in parentheses besides the taxon name). Green fields highlight taxa found only in benthos, and blue fields - taxa found only in drift during the entire study. Letters besides taxon name stand for taxa found only at barriers (B) or pools (P). Gray fields with bolded values denote taxa found with $>1000$ individuals pro the respective volume unit. Red values highlight the most numerous taxa within the single column. Abbreviations: juv. - juvenile; non det. - could not be determined.

\begin{tabular}{|c|c|c|c|c|c|c|}
\hline & & & \multicolumn{2}{|c|}{ BARRIERS } & \multicolumn{2}{|c|}{ POOLS } \\
\hline & & & Benthos & Drift & Benthos & Drift \\
\hline Class/Order & Family & $\begin{array}{l}\text { Subfamily/Genus/ } \\
\text { Species }\end{array}$ & $\begin{array}{l}\text { (Ind. } \\
\mathrm{dm}^{-3} \text { ) }\end{array}$ & $\begin{array}{c}\text { (Ind. } \\
100 \mathrm{~m}^{-3} \text { ) }\end{array}$ & $\begin{array}{l}\text { (Ind. } \\
\mathrm{dm}^{-3} \text { ) }\end{array}$ & $\begin{array}{c}\text { (Ind. } \\
100 \mathrm{~m}^{-3} \text { ) }\end{array}$ \\
\hline \multirow[t]{3}{*}{ Gastropoda } & Ancylidae & Ancylus sp. ${ }^{\text {B }}$ & 18 & & & \\
\hline & Lymnaeidae & Lymnaeidae gen. sp. ${ }^{\text {B }}$ & 55 & & & \\
\hline & Viviparidae & Viviparidae gen. sp. ${ }^{\text {B }}$ & 18 & & & \\
\hline Nematoda & Nematoda gen. sp. & Nematoda gen. sp. ${ }^{\mathrm{P}}$ & & & 350 & \\
\hline \multirow[t]{5}{*}{ Oligochaeta } & Enchytraeidae & Enchytraeidae gen. sp. & & 8528 & & 751 \\
\hline & Lumbricidae & Lumbricidae gen. sp. & 18 & & 37 & \\
\hline & & Eiseniella tetraedra ${ }^{\mathrm{B}}$ & & 266 & & \\
\hline & Lumbriculidae & Lumbriculidae gen. sp. & 1474 & 592 & 2543 & \\
\hline & Naididae & Naididae gen. sp. & 2783 & 2095 & 885 & 412 \\
\hline \multirow[t]{4}{*}{ Cladocera } & Bosminidae & Bosmina sp. ${ }^{\mathrm{P}}$ & & & 18 & \\
\hline & Chydoridae & Alona spp. & 258 & 25912 & 1788 & 4906 \\
\hline & & Chydorus sp. & & 307 & & 10 \\
\hline & Daphnidae & Daphnia sp. ${ }^{\text {в }}$ & & 10 & & \\
\hline \multirow[t]{2}{*}{ Copepoda } & Cyclopoida & Cyclopoida gen. sp. & & 1121 & & 144 \\
\hline & Harpacticoida & Harpacticoida gen. sp. & 74 & 143 & 2083 & \\
\hline Ostracoda & Ostracoda & Ostracoda gen. sp. ${ }^{p}$ & & & 55 & \\
\hline Amphipoda & Gammaridae & Gammarus balcanicus ${ }^{\mathrm{B}}$ & & 36 & & \\
\hline Arachnida & Hydrachnidia & Hydrachnidia gen. sp. & 2009 & 4926 & 663 & \\
\hline Collembola & Isotomidae & Isotomidae gen. sp. & & 11 & & 157 \\
\hline \multirow[t]{2}{*}{ Odonata } & Calopterygidae & Calopteryx sp. ${ }^{\text {B }}$ & & 68 & & \\
\hline & Gomphidae & $\begin{array}{l}\text { Onychogomphus } \\
\text { forcipatus }\end{array}$ & 55 & 202 & 92 & 24 \\
\hline \multirow[t]{2}{*}{$\begin{array}{l}\text { Ephemerop- } \\
\text { tera }\end{array}$} & Baetidae & Baetis sp. & 74 & 308 & 37 & 71 \\
\hline & Caenidae & Caenis sp. ${ }^{\mathrm{B}}$ & 37 & 89 & & \\
\hline
\end{tabular}




\begin{tabular}{|c|c|c|c|c|c|c|}
\hline & Ephemerellidae & Ephemerella notata ${ }^{\mathrm{B}}$ & & 68 & & \\
\hline & Ephemeridae & Ephemera sp. ${ }^{\mathrm{B}}$ & 18 & 2 & & \\
\hline & Heptageniidae & Rhitrogena sp. & & 340 & & 249 \\
\hline & Leptophlebiidae & Paraleptophlebia sp. & 55 & 1210 & & 540 \\
\hline \multirow[t]{8}{*}{ Plecoptera } & Leuctridae & Leuctra sp. ${ }^{\mathrm{B}}$ & & 92 & & \\
\hline & Nemouridae & Amphinemura sp. & 92 & 61 & 184 & 79 \\
\hline & & Nemoura sp. & & 77 & & 7 \\
\hline & & Nemoura juv. ${ }^{\mathrm{P}}$ & & & 37 & \\
\hline & & Protonemura sp. & 258 & 804 & 37 & 20 \\
\hline & Perlidae & Perla sp. ${ }^{\text {B }}$ & 18 & & & \\
\hline & Taeniopterygidae & Brachyptera sp. ${ }^{\mathrm{P}}$ & & & 18 & \\
\hline & juv. & non det. ${ }^{\mathrm{B}}$ & & 85 & & \\
\hline \multirow[t]{16}{*}{ Trichoptera } & Beraeidae & Beraeamyia sp. ${ }^{\mathrm{B}}$ & & 22 & & \\
\hline & Hydropsychidae & Hydropsyche sp. & 258 & 1284 & 18 & \\
\hline & Hydroptilidae & Agraylea sp. ${ }^{\mathrm{B}}$ & & 51 & & \\
\hline & & Orthotrichia sp. & & 67 & & 181 \\
\hline & & Oxyethira sp. & & 237 & & 79 \\
\hline & & Tricholeiochiton sp. & & 52 & & 27 \\
\hline & & Hydroptilidae gen. sp. & 129 & & 18 & \\
\hline & Lepidostomatidae & Lepidostoma sp. ${ }^{\mathrm{B}}$ & & 5 & & \\
\hline & Limnephilidae & Limnephilus sp. ${ }^{\mathrm{B}}$ & & 9 & & \\
\hline & Leptoceridae & Leptoceridae gen. sp. & 166 & & 461 & \\
\hline & Philopotamidae & Wormaldia sp. ${ }^{\mathrm{B}}$ & 92 & 61 & & \\
\hline & $\begin{array}{l}\text { Polycentropodi- } \\
\text { dae }\end{array}$ & Plectrocnemia sp. ${ }^{\mathrm{B}}$ & & 17 & & \\
\hline & & Polycentropus sp. ${ }^{\mathrm{P}}$ & & & & 24 \\
\hline & Psychomiidae & Tinodes sp. & 18 & 174 & & 24 \\
\hline & Rhyacophilidae & Rhyacophila spp. & 18 & 544 & & 30 \\
\hline & Sericostomatidae & Sericostoma sp. & & 7 & 37 & \\
\hline \multirow[t]{4}{*}{ Coleoptera } & Elmidae & Riolus spp. & 1585 & 6783 & 1161 & 2488 \\
\hline & & Riolus spp. (imago) & 129 & 865 & 276 & 406 \\
\hline & Scirtidae & Cyphon sp. & 387 & 17 & 55 & \\
\hline & & Elodes sp. & 866 & 1451 & 37 & 102 \\
\hline
\end{tabular}




\begin{tabular}{|l|l|l|r|r|r|r|}
\hline Diptera & Athericidae & Ibisia marginata $^{\mathrm{B}}$ & & 222 & & \\
\hline & Ceratopogonidae & $\begin{array}{l}\text { Ceratopogonidae gen. } \\
\text { sp. }\end{array}$ & & 715 & & 550 \\
\hline & Chironomidae & Chironomidae (pupae) & & 55 & & 181 \\
\hline & & Chironomini gen. sp. & 369 & 388 & 240 & 20 \\
\hline & & Orthocladiinae gen. sp. & 184 & 1462 & 184 & 766 \\
\hline & & Tanypodinae gen. sp. & 553 & 763 & 424 & 625 \\
\hline & Tanytarsini gen. sp. & & 533 & 37 & 472 \\
\hline & Dixidae & Dixa sp. & & & \\
\hline & Empididae & Hemerodromia spp. & 405 & 1932 & 479 & 674 \\
\hline & Limoniidae & Limoniidae gen. sp. & 111 & & 37 & \\
\hline & Simuliidae & Prosimulium spp. & 55 & 62 & 18 & \\
\hline & & Simulium spp. & 608 & 8072 & 166 & 1708 \\
\hline & & Simulium spp. $($ pupae) & & 149 & & \\
\hline
\end{tabular}

reach is densely covered with moss, one would expect that it would load much more particles and meio-/macrofaunal organisms (especially rheophilic species) than benthos of the counterpart moss-poor pool habitats (cf. SUREN, 1991, 1992; LinHART et al., 2002). However, whereas our moss parameters (i.e., MOSS and MAT) reached significantly higher means within barrier vs. pool benthos, other particles (i.e., CPOM, FPOM, nonMAT) as well as macroinvertebrates did not show such significant between-habitat trend. Moreover, CPOM, FPOM and non-MAT displayed the opposite (although not significant) trend, reaching higher benthic densities within pools than barriers (Fig. 5). Our findings of highest moss densities in fast-flow habitats (i.e., barriers) correspond to those of Suren (1991) within the two New Zealand alpine streams, but they oppose the study of HabDija et al. (2004), who also carried out their research within the Plitvice Lakes hydrosystem (in four different flow conditions ranging in flow velocity from 0,2 $\mathrm{m} \mathrm{s}^{-1}$ to $>1 \mathrm{~m} \mathrm{~s}^{-1}$ ), but they found a decrease in moss biomass with an increase in flow velocity. Considering the differing findings across more-less similar habitats, we could suggest that moss densities within stream benthos depend not only on mean local flow velocities, but also on the overall background hydraulic conditions (e.g., shear stresses, total turbulence energy) (NiкоRA et al., 1998) as well as on the season, altitude, slope and local water conductivity (Pentecost, 1991; Suren, 1991).

The observed CPOM, FPOM and non-MAT benthic patterns were to some extent in contrast to previous findings within the Plitvice Lakes hydrosystem (e.g., MilıšA et al., 2006a). Whereas in our study CPOM, FPOM and non-MAT were denser in pools vs barriers, the benthic amounts of CPOM found by MiLIšA et al. (2006a) reached the highest densities in fast-flowing habitats, following the respective moss patterns, while FPOM accumulated the most densely in slow-flowing reaches. It is most likely that moss mats, because of their filamentous texture, are not efficient enough to trap and retain large 
amounts of both coarse and fine particles within fast-flowing reaches (MiLišA et al., 2006a). Studying the effects of in-stream habitat structure and discharge on leaf (i.e., CPOM) retention, Koljnonen et al. (2012) observed that at low discharges most natural in-stream retention structures (i.e, boulders, wood of different sizes, moss) are very efficient retention elements; whereas at high discharges, most of the retention mechanisms lose their retentive power. The exception is wood of different sizes, which was proven to remain highly retentive at all discharges, especially if appears abundant within streams (Koljnonen et al., 2012). The weakening of the moss retentive power at high discharges could be an explanation of the lower CPOM, FPOM and non-MAT accumulation at our fast-flowing barrier sites. It could have also caused the observed reversed trends of the maximum accumulated MOSS and CPOM amounts between barrier and pool benthos in the seasons of enhanced withering and dislodgement of annual aquatic vegetation (i.e., autumn, winter), and/or development of new (i.e., fragile and weakly retentive) moss outgrowths (i.e., spring) (Fig. 6a).

The observed drift-benthos patterns suggest that it is not only habitat patchiness (i.e., substrate composition, moss presence and retentiveness) that influenced drift-benthos patterns within our study reach (cf. BRooKs et al., 2005). Another very important factor largely affecting the spatial distribution of particulate matter and macroinvertebrate assemblages is most likely the varying flow velocity among the study sites, which is a clear consequence of the alternating barrier-pool (i.e., lotic-lentic) sequence along the study reach (ŠPOLJAR et al., 2007a, b).

It is very likely that faster flows at the barrier sites increase the particle/organism resuspension and their downstream transport/drift. The increased flow velocities erode (i.e., dislodge) the substrate (e.g., moss) and substrate-associated particles and organisms, and often prevent their settling, especially if they are small (SPEAKer et al., 1984; FonseCA, 1999). Once dislodged from the stream bed, larger particles (e.g., CPOM and MOSS) exhibit higher sinking rates, spending less time in the water column and reaching the stream bed faster than the smaller particles (Отто \& Sјöströм, 1985; FonSECA, 1999). Whereas the larger particles are less affected by flow oscillations, abrupt flow changes and water column conditions and they easily get settled in the pool habitats, the finer particles are mostly "kept in drift" by the turbulence (FonsecA, 1999). Thus, it is not surprising that in the present study particle drift composition significantly differed between barriers and pools. Our findings suggest that the fast-flowing barrier sites experience a considerable flow-induced substrate "denudation" (i.e., pronounced dislodgment and "flushing" of the moss and moss-attached particles/organisms from the substrate), which then mitigates the differences in benthos composition between barriers and pools. At the same time, it likely causes the conspicuous differences in macroinvertebrate/particle drift between the two habitat types.

Similar to our findings, a few other experimental and modelling studies have attributed riffles as "sources" (i.e., production areas), and pools as "sinks" (i.e., consumption areas) of benthic drift (Rosenfeld \& REABURn, 2009; Rosenfeld \& TAYlOR, 2009; Hauer et al., 2012). Moreover, these studies indicated that the alteration patterns of the riffle-pool sequences within a hydrosystem could greatly affect not only the downstream drift and benthic assemblies, but also fish communities, i.e. the fish production, foraging strategies (drift vs. limnetic feeding) and internal (i.e., within-stream) prey subsidies. In this regard, interest has also been paid to the ecological and hydraulic features of "step-pool" systems, which are similar to barrier-pool sequences within our study system, but occur mainly in high-gradient mountain streams and have a stairlike appearance with 
alternating steps (composed of cobbles and boulders) and pools (with finer sediments deposited behind the steps) (e.g., Montgomery \& Buffington, 1997; Chin, 1999). It has been proven that such cascading systems have a stabilizing effect on the streambed as they dissipate the kinetic energy of fast moving water (WoHL, 2000), providing high habitat diversity for stream biocommunities as well as storage sites for finer bed material. We suggest that the "barrier-pool" sequences within our study system have the analogous effect on the streambed and benthic communities.

\section{Seasonal drift-benthos trends}

Whereas the seasonal means of the benthic parameters measured in this study generally demonstrated relatively even distribution at barriers and pools over the year, the relevant drift patterns yielded clear differences pointing to barriers as zones of particle and organism dispersal during autumn and winter. The same drift trend was previously reported by Sertić Perić et al. (2011, 2014), but the previous studies lacked the relevant benthic data and adequate comparisons on the drift-benthos relationships, respectively.

Rare studies evidence the non-significant seasonal variation of macroinvertebrate benthic densities, as it has been demonstrated in the present study (e.g., O'ConNor \& Lake, 1994; Ramírez \& Pringle, 1998; Baptista et al., 2001). Most previous studies from temperate regions evidence the conspicuous seasonal trends of both drift and benthos, mostly dependent on the stream type, hydrological and geomorphological characteristics (e.g., Townsend \& Hildrew, 1976; Brittain \& Eikeland, 1988; Robinson et al., 2004). However a few tropical studies have shown a lack of drift-benthos seasonality, suggesting that invertebrate populations in tropical region grow and reproduce continuously during the entire year, likely because they are exposed to similar environmental conditions throughout the year (BritTAin \& Eikeland, 1988; RAmírez \& Pringle, 1998); whereas a lack of distinct seasonal patterns in drift within alpine streams was mainly attributed to great spatio-temporal heterogeneity/variability of the alpine stream habitats and their flow conditions throughout a year (Hieber et al., 2003; Sertić Perić \& Robinson, 2015).

As previously discussed by Sertić Perić et al. (2011, 2014), seasonality in drifting invertebrates along our study reach is clearly associated to seasonal shifts in in-stream vegetation (i.e., moss) associated with seasonal changes in water temperature, hydrochemistry, flow conditions (i.e., discharge, flow velocity; Figs. 2 and 4), and transported organic matter, which most likely serves as an important vector for the flow-mediated macroinvertebrate dispersal (Fig. 6). However, it is important to point out that our autumn and winter sampling occasions were characterized by high flow conditions (i.e., hydropeaking events), whereas spring and summer samplings occurred during a declining hydrograph (i.e., 4 and 12 days after a discharge peak, respectively) (Fig. 2). It is obvious that the hydropeaking events coincided with maxima, and post-hydropeaking periods with minima of transported streambed material and drifting macroinvertebrates at the barriers. Considering the increased amounts of drifting particles and organisms within pools during our spring and summer sampling occasions (Figs. 2, 6 and 7), we could suggest that declining hydrographs are periods of settling of the bedload and organisms dislodged from the barriers during the preceding high discharges (cf. CAsTElla et al., 1995; WoOd \& ARMitage, 1999). Increases in drift density have been repeatedly observed in response to discharge rises associated with hydropeaking, experimen- 
tal and/or natural floods - such drift is mostly considered as passive drift, and it decreases during low-flow-periods (e.g., Poff \& WARD, 1991; Robinson et al., 2004; MCKINNEY et al., 2009). However, many studies have shown that declining hydrographs could indicate the periods of increased active drift, which is usually attributed to behavioral movements of macroinvertebrates (PofF \& WARD, 1991; NEGISHI \& RicHARDSON, 2006).

In general, drift-benthos patterns observed along our study reach demonstrate that drift and benthos were continuously taxonomically similar. However, the quantitative composition (i.e., contribution of individual taxa to overall benthos and drift densities) indicated some seasonal and taxon-specific drift-benthos inconsistencies. As drifting invertebrates (and particles) are mostly derived from the benthos (sensu the benthic-drift hypothesis; HILDEBRAND, 1974), we would expect that invertebrate drift is proportional to the relevant benthic composition at the particular site (as proven by e.g., SHEARER et al., 2003; Tonkin \& DeATH, 2013). It is most likely that the observed inconsistencies between drift and benthos (Fig. 7) resulted from the fact that drift actually integrates populations (and particles) from different communities (and patches) of a stream (and the upstream lake) section (WAters, 1965, 1972; Hynes, 1970; Sertić Perić et al., 2011, 2014); and that temporal patterns of drift and benthos (composition and density) largely depend on varying flow rates and their effect on the organism/particle dislodgement and transport, as well as on the seasonal upstream lake discharges and associated biocommunity (i.e., plankton, macrozoobenthos, aquatic vegetation) dynamics, and life history traits of the individual aquatic organisms (BIRD \& Hynes, 1981; LANCASTER et al., 1996; Shearer et al., 2002; Sertić Perić et al., 2011, 2014).

The fauna found dominating in benthos and/or drift (e.g., Oligochaeta, Alona spp., Riolus spp., Simulium spp.) at both habitat types mostly belong to mobile, surface (i.e., epiphytic) or interstitial detritivores often found within submerged aquatic vegetation (i.e., moss), floating leaf litter or as sediment-dwelling (SERTić Perić et al., 2011, 2014 and references therein). We hypothesize that they are dislodged together with the substratum material, and thus demonstrate almost the same drift-benthos patterns as the organic and inorganic particles. Moreover, as the occurrence of drifting moss is an annually repeated phenomenon, we suggest that the moss-attached invertebrate fauna might play an important role in facilitating the seasonal moss breakdown (i.e., fragmentation), dislodgement, and decomposition, while utilizing them as food source and/or refuge (cf. Norкко et al., 2000). Cladocerans, particularly numerous in summer and autumn along our study reach, clearly originated from the upstream Veliki Burget lake during the seasonal excess production of the lake, similarly as it has been shown in the previous lake outlet studies (Brittain \& Eikeland, 1988; Hieber et al., 2003; Sertić Perić et al., 2011).

The taxa found only or mostly in benthos (i.e., Gastropoda and larger Trichoptera) are able to resist drift probably because they remain firmly attached to hard substratum even in fast and turbulent flows (e.g., Thorp \& Соvich, 1991). On the other hand, the recorded succession in the faunal drift-benthos composition, with different taxa appearing/dominating at different times (e.g., Cladocera increase in summer and autumn, Ephemeroptera decrease/absence in winter and spring) (Fig. 8), is likely a consequence of the seasonal resource availability for individual taxa, and the taxa life history traits and strategies linked to life span, survival, mobility and dispersal mode (Siler et al., 2001; VERBERK et al., 2008). 
Considering the observed macrozoobenthos stability, but the varying drift trends along our study reach over different seasons, it becomes clear that drift has a very important role in maintaining benthos structure and stability at the barrier and pool habitats (i.e., waterfall sites) within the investigated karst barrage system. Moreover, we could infer that drift indeed is critical to maintenance of benthic invertebrate populations and for ecological connectivity within streams, especially at finer spatial scales (cf. BRITTAIN \& Eikeland, 1988; LANCASTER et al., 1996; HART \& Finelli, 1999; Wipfli et al., 2007). Indirectly, our seasonal drift-benthos observations also support the notion that tufa barriers are highly dynamic habitats characterized by pronounced season-specific dislodgement of the benthic organisms and particulate matter, and effective moss-mediated macroinvertebrate dispersal within the investigated tufa-precipitating system (as previously suggested by Sertić Perić et al., 2011, 2014). We suggest that the complex interplay between alternating high- and low-flow periods and barrier-pool drift patterns vastly influences the benthos stability and sustainability within our study system, especially considering the flux of material and organisms taking part in tufa precipitation within Plitvice Lakes. However, to integrate our conclusions into a larger context (i.e., entire lake cascade), larger scale research would be needed, as our study was designed to only examine drift patterns at the small spatial scale over a one-year period.

\section{ACKNOWLEDGEMENTS}

This research was funded by the Croatian Ministry of Science, Education and Sports, project no. 119-0000000-1205. We are very grateful to the management and staff of the Plitvice Lakes National Park for supporting this study and allowing access to the study sites. We also thank Martin Lacayo Emery for English proofreading.

Received March 4, 2015

\section{REFERENCES}

Allan, J. D., 1995: Stream Ecology. Chapman \& Hall, New York, 388 pp.

Amoros, C., 1984: Introduction pratique à la systématique des organismes des eaux continentales françaises. Crustacés cladocères. Bulletin Bimensuel de la Société Linnéenne de Lyon 53, 72-105.

Baptista, D. F., Dorvillé, L. F. M., Buss, D. F. \& Nessimian, J. L., 2001: Spatial and temporal organization of aquatic insect assemblages in the longitudinal gradient of a tropical river. Brazilian Journal of Biology 61, 295-304.

BAUERNFEIND, E. \& Humpesch, U. H., 2001: Die Eintagsfliegen Zentraleuropas (Insecta: Ephemeroptera): Bestimmung und Ökologie. Verlag des Naturhistorischen Museums, Wien, 239 pp.

Belančić, A., Matoničkin Kepčija, R., Miliša, M., Plenković-Moraj, A. \& Habdija, I., 2009: Flow velocity effect on leaf litter breakdown in tufa depositing system (Plitvice Lakes, Croatia). International Review of Hydrobiology 94, 391-398.

Bird, G. A. \& Hynes, H. B. N., 1981: Movement of immature aquatic insects in a lotic habitat. Hydrobiologia $77,103-112$.

Brittain, J. E. \& Eikeland, T. J., 1988: Invertebrate drift - a review. Hydrobiologia 166, 77-93.

Brooks, A. J., Haeusler, T., Reinfelds, I. \& Williams, S., 2005: Hydraulic microhabitats and the distribution of macroinvertebrate assemblages in riffles. Freshwater Biology 50, 331-344.

Carthew, K. D., Taylor, M. P. \& Drysdale, R. N., 2002: Aquatic insect larval constructions in tropical freshwater limestone deposits (tufa): preservation of depositional environments. General and Applied Entomology: the Journal of the Entomological Society of New South Wales 31, 35-41.

Castella, E., Bickerton, M., Armitage, P. D. \& Petts, G. E., 1995: The effects of water abstractions on invertebrate communities in U.K. streams. Hydrobiologia 308, 167-182. 
CHIN, A., 1999: The morphologic structure of step-pools in mountain streams. Geomorphology 27, 191204.

Di Sabatino, A., Gerecke, R. \& Martin, P., 2000: The biology and ecology of lotic water mites (Hydrachnidia). Freshwater Biology 44, 47-62.

Dražina, T., Šroljar, M., Primc, B. \& HabdiJa, I., 2013: Small-scale patterns of meiofauna in a bryophyte covered tufa barrier (Plitvice Lakes, Croatia). Limnologica 43, 405-416.

Elliotr, J. M., 1969: Diel periodicity in invertebrate drift and the effect of different sampling periods. Oikos 20, 524-528.

FAULKNER, H. \& Copp, G. H., 2001: A model for accurate drift estimation in streams. Freshwater Biology 46, 723-733.

FonsECA, D. M., 1999: Fluid-mediated dispersal in streams: models of settlement from the drift. Oecologia 121, 212-223.

Golubić, S., Violante, C., Plenković-Moraj, A. \& Grgasović, T., 2008: Travertines and calcareous tufa deposits: an insight into diagenesis. Geologia Croatica 61, 363-378.

Habdija, I., Primc-Habdija, B., MatoničKin, R., Kučinić, M., Radanović, I., Miliša, M. \& Mihaljević, Z., 2004: Current velocity and food supply as factors affecting the composition of macroinvertebrates in bryophyte habitats in karst running water. Biologia 59, 577-593.

Hart, D. D. \& Finelli, C. M., 1999: Physical-biological coupling in streams: the pervasive effects of flow on benthic organisms. Annual Review of Ecology, Evolution, and Systematics 30, 363-395.

Hauer, C., Unfer, G., Graf, W., Leitner, P., Zeiringer, B. \& Habersack, H., 2012: Hydro-morphologically related variance in benthic drift and ist importance for numerical habitat modelling. Hydrobiologia 683, 83-108.

Hieber, M., Robinson, C. T. \& Uehlinger, U., 2003: Seasonal and diel patterns of invertebrate drift in different alpine stream types. Freshwater Biology 48, 1078-1092.

Hildebrand, S. G., 1974: The relation of drift to benthos density and food level in an artificial stream. Limnology and Oceanography 19, 951-957.

Hoover, T. M., Marczak, L. B., Richardson, J. S. \& Yonemitsu, N., 2010: Transport and settlement of organic matter in small streams. Freshwater Biology 55, 436-449.

Hynes, H. B. N., 1970: The Ecology of Running Waters. University of Toronto Press, Toronto, 555 pp.

Knoz, J., 1965: To identification of Czechoslovakian black-flies (Diptera, Simuliidae). Folia Facultatis Scientiarum Naturalium Universitatis Purkynianae Brunensis 6, 1-52.

Koljonen, S., Louni, P., Mäкi-Peтӓys, A., Нuusкo, A. \& MuotкA, T., 2012: Quantifying the effects of instream habitat structure and discharge on leaf retention: implications for stream restoration. Freshwater Science 31, 1121-1130.

LAmberti, G. A. \& Gregory, S. V., 2007: CPOM transport, retention, and measurement. In: Hauer, F. R. \& Lamberti, G. A. (eds.), Methods in Stream Ecology, 2nd edition. Academic Press/Elsevier, New York. p. $273-289$.

Lancaster, J., Hildrew, G. A. \& GJeRKov, C., 1996: Invertebrate drift and longitudinal transport processes in streams. Canadian Journal of Fisheries and Aquatic Sciences 53, 572-582.

LinHART, J., VLČKOVÁ, Š. \& UvíRA, V., 2002: Bryophytes as a special mesohabitat for meiofauna in a riprapped channel. River Research and Applications 18, 321-330.

Margaritora, F. G., 1983: Cladoceri (Crustacea: Cladocera). Guide per il Riconoscimento delle Specie Animali delle Acque Interne Italiane. Stamperia Valdonega, Verona, $168 \mathrm{pp}$.

MatoničKin Kepčija, R., Habdija, I., Primc-Habdija, B. \& Miliša, M., 2006: Simuliid silk pads enhance tufa deposition. Archiv für Hydrobiologie 166, 387-409.

Mckinney, T., Ayers, A. D. \& Rogers, R. S., 2009: Macroinvertebrate drift in the tailwater of a regulated river below Glen Canyon Dam , Arizona. Southwestern Naturalist 44, 205-210.

Miliša, M., Habdija, I., Primc-Habdija, B., Radanović, I. \& Matoničkin Kepčija, R., 2006a: The role of flow velocity in the vertical distribution of particulate organic matter on moss-covered travertine barriers of the Plitvice Lakes (Croatia). Hydrobiologia 553, 231-243.

Miliša, M., MatoničKin Kepčija, R., Radanović, I., Ostojić, A. \& Habdija, I., 2006b: The impact of aquatic macrophyte (Salix sp. and Cladium mariscus (L.) Pohl.) removal on habitat conditions and macroinvertebrates of tufa barriers (Plitvice Lakes, Croatia). Hydrobiologia 573, 183-197.

MontgomerY, D. R. \& Buffington, J. M., 1997: Channel-reach morphology in mountain drainage basins. Geological Society of America Bulletin ${ }_{109}, 596-611$. 
Muotka, T. \& LAasonen, P., 2002: Ecosystem recovery in restored headwater streams: the role of enhanced leaf retention. Journal of Applied Ecology 39, 145-156.

Negishi, J. N. \& Richardson, J. S., 2006: An experimental test of the effects of food resources and hydraulic refuge on patch colonization by stream macroinvertebrates during spates. Journal of Animal Ecology 75, 118-129.

Nikora, V. I., Suren, A. M., Brown, S. L. R., \& Biggs, B. J. F., 1998: The effects of the moss Fissidens rigidulus (Fissidentaceae: Musci) on near-bed flow structure in an experimental cobble bed flume. Limnology and Oceanography 43, 1321-1331.

Nilsson, A. (ed.), 1996: Aquatic Insects of North Europe. A taxonomic handbook. Vol. 1: Ephemeroptera. Plecoptera, Heteroptera, Magaloptera, Neuroptera, Coleoptera, Trichoptera and Lepidoptera. Apollo Books, Stenstrup, 274 pp.

Nilsson, A. (ed.), 1997: Aquatic Insects of North Europe. A taxonomic handbook, Vol. 2: Odonata. Diptera. Apollo Books, Stenstrup, $440 \mathrm{pp}$.

Norkкo, J., Bonsdorff, E. \& Norkко, A., 2000: Drifting algal mats as an alternative habitat for benthic invertebrates: Species specific responses to a transient resource. Journal of Experimental Marine Biology and Ecology 248, 79-104.

O'Connor, N. A. \& LAKE, P. S., 1994: Long-term and seasonal large-scale disturbances of a small lowland stream. Australian Journal of Marine \& Freshwater Research 42, 243-255.

Отто, C. \& Sјӧsтröм, P., 1985: Behaviour of drifting insect larvae. Hydrobiologia 131, 77-86.

Pedley, H. M. \& Rogerson, M. (eds), 2010: Tufas and Speleothems: Unravelling the Microbial and Physical Controls. Geological Society, London, Special Publications, 336.

Pentecost, A., 1991: Algal and bryophyte flora of a Yorkshire (U.K.) hill stream: a comparative approach using biovolume estimation. Archiv für Hydrobiologie 121, 181-201.

Pentecost, A. , 2005: Travertine. Springer-Verlag Berlin, Heidelberg, 445 pp.

Poff, N. L. \& WARD, J. V., 1991: Drift responses of benthic invertebrates to experimental streamflow variation in a hydrologically stable stream. Canadian Journal of Fisheries and Aquatic Sciences 48, 19261936.

Primc-Habdija, B., Habdija, I. \& Plenković-Moraj, A., 2001: Tufa deposition and periphyton overgrowth as factors affecting the ciliate community on travertine barriers in different current velocity conditions. Hydrobiologia 457, 87-96.

Ramírez, A. \& Pringle, C. M., 1998: Invertebrate drift and benthic community dynamics in a lowland neotropical stream, Costa Rica. Hydrobiologia 386, 19-26.

Robinson, C. T, Tockner, K. \& Burgherr, P., 2004: Drift benthos relationships in the seasonal colonization dynamics of alpine streams. Archiv für Hydrobiologie 160, 447-470.

Rosenfeld, J. S. \& REABURn, E., 2009: Effects of habitat and internal prey subsidies on juvenile coho salmon growth: implications for stream productive capacity. Ecology of Freshwater Fish 18, 572-584.

Rosenfeld, J. S. \& TAYlor, J., 2009: Prey abundance, channel structure and the allometry of growth rate potential for juvenile trout. Fisheries Management and Ecology 16, 202-218.

Schmedtje, U. \& Kohmann, F., 1988: Bestimmungsschlüssel für die Saprobier-DIN-Arten (Makroorganismen). Bayerisches Landesamt für Wasserwirtschaft, München, 274 pp.

Sertić Perić, M., Dražina, T., Špoljar, M., Radanović, I., Primc, B. \& Habdija, I., 2014: Meiofauna constitute a considerable portion of invertebrate drift among moss-rich patches within a karst hydrosystem. Biologia (Bratislava) 69, 363-380.

Sertić Perić, M., Miliša, M., Matoničkin Kepčija, R., Primc-Habdija, B. \& Habdija, I., 2011: Seasonal and fine-scale spatial drift patterns in a tufa-depositing barrage hydrosystem. Fundamental and Applied Limnology 178, 131-145.

Sertić Perić, M. \& Robinson, C. T., 2015: Spatio-temporal shifts of macroinvertebrate drift and benthos in headwaters of a retreating glacier. Hydrobiologia 751, 25-41.

SheArer, K. A., Hayes, J. W. \& StArk, J. D., 2002: Temporal and spatial quantification of aquatic invertebrate drift in the Maruia River, South Island, New Zealand. New Zealand Journal of Marine and Freshwater Research 36, 529-536.

Shearer, K. A., Stark, J. D., Hayes, W. J. \& Young, G. R., 2003: Relationships between drifting and benthic invertebrates in three New Zealand rivers: implications for drift feeding fish. New Zealand Journal of Marine and Freshwater Research 37, 809-820.

Siler, E. R, WALlace, J. B. \& EgGert, S. L., 2001: Long-term effects of resource limitation on stream invertebrate drift. Canadian Journal of Fisheries and Aquatic Sciences 58, 1624-1637. 
Sмоск, L. A., 2007: Macroinvertebrate dispersal. In: Hauer, F. R. \& LAmberti, G. A. (eds.), Methods in Stream Ecology, 2nd edition. Academic Press/Elsevier, New York. p. 465-487.

SPEAKer, R., MoORE, K. \& GregorY, S., 1984: Analysis of the process of retention of organic matter in stream ecosystems. Verhandlungen der Internationalen Vereinigung für Theoretische und Angewandte Limnologie 22, 1835-1841.

Srdoč, D., Horvatinčić, N., Obelić, B., Krajcar, I. \& SliepČević, A., 1985: Calcite deposition processes in karst waters with special emphasis on the Plitvice Lakes, Yugoslavia (in Croatian). Carsus Iugoslaviae 11, 101-204.

STATSOFT, INC., 2010: STATISTICA (data analysis software system), version 9.1, www.statsoft.com.

Sundermann, A. \& Lohse, S., 2004: Bestimmungsschlüssel für die aquatischen Zweiflügler (Diptera) in An-lehnung an die Operationelle Taxaliste für Fließgewässer in Deutschland. In: HAAsE, P. \& SundERMANN, A. (eds), Standardisierung der Erfassungs- und Auswertungsmethoden von Makrozoobenthosuntersuchungen in Fließgewässern. Abschlussbericht zum LAWA-Projekt O 4.02. http://www. fliessgewaesserbewertung.de

Suren, A. M. \& Winterbourn, M. J., 1992: The influence of periphyton, detritus and shelter on invertebrate colonization of aquatic bryophytes. Freshwater Biology, 27, 327-339.

Suren, A. M., 1991: Bryophytes as invertebrate habitat in two New Zealand alpine streams. Freshwater Biololy 26, 399-418.

SuREN, A. M., 1992: Enhancement of invertebrate food resources by bryophytes in New Zealand alpine headwater streams. New Zealand Journal of Marine and Freshwater Research 26, 229-239.

Špoljar, M., Habdija, I. \& Primc-Habdija, B., 2007a: The influence of the lotic and lentic stretches on the zooseston flux through the Plitvice Lakes (Croatia). Annales de Limnologie - International Journal of Limnology 43, 29-40.

Špoljar, M., Primc-Habdija, B. \& Habdija, I., 2007b: Transport of seston in the karstic hydrosystem of the Plitvice Lakes (Croatia). Hydrobiologia ${ }_{579}, 199-209$.

Tachét, H., Richoux, P., Bournaud, M. \& Usseglio-Polatera, P., 2000: Invertébrés d'Eau Douce. Systématique, Biologie, écologie. CNRS éditions, Paris, $588 \mathrm{pp}$.

ThoRp, J. H. \& Covich, A. P., 1991: Ecology and Classification of North American Freshwater Invertebrates. Academic Press, Inc. New York, New York, USA, 1056 pp.

Tonkin, J. D. \& Death, R. G., 2013: Macroinvertebrate drift-benthos trends in a regulated river. Fundamental and Applied Limnology 182, 231-245.

Townsend, C. R. \& Hildrew, A. G., 1976: Field experiments on the drifting, colonization and continuous redistribution of stream benthos. Journal of Animal Ecology 45, 759-772.

Verberk, W. C. E. P., SiepeL, H. \& EsselinK, H., 2008: Life-history strategies in freshwater macroinvertebrates. Freshwater Biology 53, 1722-1738.

Wallace, J. B., Hutchens, JR., J. J. \& Grubaugh, J. W., 2007: Transport and storage of FPOM. In: Hauer, F. R. \& Lamberti, G. A. (eds.), Methods in Stream Ecology, 2nd edition. Academic Press/Elsevier, New York. p. 249-272.

WARINGER, J. \& GRAF, W., 1997: Atlas der Österreichischen Köcherfliegenlarven. Facultas Universitätsverlag, Wien, $286 \mathrm{pp}$.

WATERS, T. F., 1965: Interpretation of invertebrate drift in stream. Ecology 46, 327-334.

Waters, T. F., 1972: The drift of stream insects. Annual Review of Entomology 17, 253-272.

Wipfli, M. S., Richardson, J. S. \& Naiman, R. J., 2007: Ecological linkages between headwaters and downstream ecosystems: transport of organic matter, invertebrates, and wood down headwater channels. Journal of the American Water Resources Association (JAWRA) 43, 72-85.

WoHL, E. E., 2000: Mountain Rivers. American Geophysical Union, Washington, D.C., 320 pp.

Wood, P. J. \& Armitage, P. D., 1999: Sediment deposition in a small lowland stream-management implications. Regulated Rivers: Research \& Management 15, 199-210.

ZAR, J. H., 1984: Biostatistical Analysis. Prentice Hall, Englewood Cliffs, 718 pp.

Zwick, P., 2004: Key to the West Palaearctic genera of stoneflies (Plecoptera) in the larval stage. Limnologica 34, 315-348. 


\title{
SAŽETAK
}

\section{Sezonski trendovi drifta i bentosa na mahovinom prekrivenim sedrenim barijerama unutar krškog baražnog hidrosustava (Plitvička jezera, Hrvatska)}

\author{
M. Sertić Perić, S. Jakopović \& B. Primc
}

\begin{abstract}
Životne zajednice lotičkih staništa razvile su brojne morfološke, fiziološke i etološke prilagodbe vezane uz mogućnost svladavanja strujanja vode. Drift ili nizvodno otplavljivanje organizama uzrokovano strujom vode najvažniji je mehanizam rasprostiranja bentičkih beskralježnjaka u lotičkim ekosustavima. Pored organizama, struja vode nosi i usitnjene organske i anorganske čestice različitog porijekla i veličine. Nizvodno otplavljivanje tvari i organizama stoga predstavlja važan mehanizam (pre)raspodjele energetskih izvora i građevnih elemenata staništa u lotičkim ekosustavima. Cilj ovog istraživanja bio je istodobno istražiti sezonske trendove drifta i bentosa na barijerama i u ujezerenjima na maloj prostornoj skali unutar krškog baražnog hidrosustava Plitvičkih jezera. Uzorkovanja makrobeskralježnjaka i usitnjene organske/anorganske tvari u driftu i bentosu provedena su sezonski, u razdoblju između studenog 2006. i srpnja 2007., na četiri postaje raspoređene na maloj prostornoj skali, duž jednog slapišta u hidrosustavu Plitvičkih jezera. Odabrane postaje (B1, B2, P1, P2) smještene su na dva tipa staništa, međusobno različita po brzini strujanja vode i sastavu supstrata: 1) barijerama (B; staništa s brzom strujom vode i obilnim mahovinskim pokrovom) i 2) ujezerenjima (P; staništa sa sporom strujom vode i oskudnijim mahovinskim pokrovom). Za razliku od drifta, tijekom cijelog razdoblja istraživanja, između bentosa barijera i bentosa ujezerenja nisu utvrđene značajnije razlike u ukupnoj brojnosti makrozoobentosa i količini organskih/anorganskih tvari, unatoč mnogo bogatijem mahovinskom pokrovu u bentosu barijera. Također, ukupna brojnost makrozoobentosa i količina organskih/anorganskih tvari $\mathrm{u}$ bentosu nisu pokazale osobite sezonske trendove između dva tipa staništa, dok je drift imao jasan sezonski trend - $u$ jesen i zimu, količine svih mjerenih parametara drifta bile su značajno više na barijerama nego u ujezerenjima. Na oba tipa staništa, taksonomski sastav drifta uglavnom je odražavao sastav bentosa. Međutim, u driftu su pronađeni organizmi koji nisu bili zastupljeni u bentosu i obrnuto. Ukupno tijekom istraživanja nađene su 63 svojte u uzorcima bentosa i drifta - od toga je 5 svojti nađeno samo u ujezerenjima, 38 samo na barijerama, a 20 svojti na oba tipa staništa. Najdominantniji i u bentosu i u driftu bili su Oligochaeta, rašljoticalac Alona spp., Copepoda te ličinke kornjaša Riolus spp. i dvokrilaca Simulium spp. Većina njih pripada mobilnim, epifitskim i/ili intersticijskim detritivorima, za koje pretpostavljamo da na našim postajama istraživanja dolaze na podvodnoj vegetaciji (tj. mahovini), plutajućim listovima i/ili u samom supstratu, dok za predstavnike Cladocera i Copepoda smatramo da potječu iz uzvodnog jezera. Opažene sezonske trendove u taksonomskom sastavu drifta i bentosa (npr. povećanje brojnosti Cladocera u ljeto i jesen; smanjenje brojnosti/odsutnost Ephemeroptera u proljeće i zimu) objašnjavamo kao posljedicu sezonskih razlika u izvorima hrane i životnim ciklusima pojedinih svojti. Ukupna brojnost organizama u bentosu i driftu uvelike je pratila količinske trendove mahovina i usitnjene organske/anorganske tvari te se može zaključiti da se mahovinama može pripisati vrlo važna uloga prijenosnika (vektora) pri pronosu tvari i organizama u lotičkim sedrotvornim sustavima. Nadalje, naši rezultati ukazuju da u sedrotvornom sustavu Plitvičkih jezera, zbog velikih brzina strujanja vode, na barijerama vjerojatno dolazi do značajnog "ogoljivanja" supstrata, što je potencijalno uzrok ublažavanja razlika u sastavu bentosa, ali i istodobnog povećavanja razlika u sastavu drifta između barijera i ujezerenja. Zaključujemo da u istraživanom krškom baražnom sustavu: a) drift ima vrlo važnu ulogu u održavanju strukture
\end{abstract}


bentosa na različitim tipovima staništa (na barijerama i u ujezerenjima); b) sedrene barijere su vrlo dinamična staništa, u kojima je snažno izraženo sezonsko otplavljivanje bentoskih organizama i usitnjene organske/anorganske tvari, a osobito mahovina kojima se može pripisati vrlo važna uloga prijenosnika pri nizvodnom transportu tvari i organizama; c) na brojnost makrozoobentosa i količinu organskih/anorganskih tvari u driftu, izuzev brzine strujanja vode i sezonskih razlika u jezerskom utjecaju (tj. jezerskom protoku i životnim zajednicama), u velikoj mjeri utječu i inicijalni sastav i raspodjela čestica/organizama u bentosu te ekološko-etološke osobitosti pojedinih skupina organizama. 